\title{
ASSESSMENT ON Trichoderma spp. MIXTURE AS A POTENTIAL BIOCONTROL AGENT OF Ganoderma boninense INFECTED OIL PALM SEEDLINGS
}

\author{
MUSA, $\mathrm{H}^{\star}$; NUSAIBAH, $\mathrm{S}^{\star *}$ and KHAIRULMAZMI, $\mathrm{A}^{\star *}$
}

\begin{abstract}
Diseases caused by Ganoderma spp. have been causing serious oil palm yield losses and affecting its contribution to the producers' economy. Research on sustainable and eco-friendly remedy to counter the disease is on the upsurge. Trichoderma spp. have been the most studied and valued microbes as biological control agents (BCA) in an effort to combat a wide range of plant diseases. Therefore, in this current study, the potential of Trichoderma spp. (Trichoderma asperellum, Trichoderma harzianum, and Trichoderma virens) as a mixture was evaluated as a BCA against basal stem rot disease of oil palm. The mixture of Trichoderma spp. demonstrated a disease reduction of $83.03 \%$ and $89.16 \%$ from the foliar and bole symptoms, respectively. The highest peroxidase (PO) level was detected in T1 (167.9 $\mathrm{U} \mathrm{g} \mathrm{g}^{-1}$ tissue) at four months after post inoculation (mpi), and the lowest in T5 (72.3 $\mathrm{U} \mathrm{g}^{-1}$ tissue) at 1 mpi. Treatment 4 with all the three Trichoderma spp. displayed the maximum level of polyphenol oxidase (PPO) among all the treatments conducted. Similarly, T4 recorded the highest accumulation of total phenolic content (TPC) (49.6 mg g $\left.\mathrm{g}^{-1}\right)$ in the seedling roots at harvest. Disease infestation was slower in Trichoderma treated seedlings regardless of a single or mixture application compared to the positive control.
\end{abstract}

Keywords: basal stem rot disease, oil palm, Trichoderma spp., peroxidase, polyphenol oxidase, total phenolic content

Date received: 16 December 2016; Sent for revision: 13 March 2017; Received in final form: 30 March 2018 ; Accepted: 5 July 2018.

\section{INTRODUCTION}

Oil palm (Elaies guineensis Jacq.) is an economically imperative plantation crop, grown primarily for its vegetable oil and has become one of the main oil crops in the world. It is the world's highest yielding oil crop known today, producing approximately 4 to $5 \mathrm{t}$ of crude palm oil (CPO) per hectare per year and about $1 \mathrm{t}$ of palm kernels (MPOC, 2017). Ganoderma spp. are the causative agents of basal stem rot (BSR)

\footnotetext{
* Department of Crop Science, Faculty of Agriculture, Federal University Dutse, PMB 7158 Dutse, Nigeria.

** Department of Plant Protection, Faculty of Agriculture, Universiti Putra Malaysia, 43400 UPM Serdang, Selangor, Malaysia E-mail: nusaibah@upm.edu.my
}

and upper stem rot (USR) (Hasan et al., 2005; Rakib et al., 2014; 2015). In Malaysia, the disease incidences (DI) are higher in oil palm plantations located on the coastal soil (Khairuddin and Chong, 2008). Ganoderma boninense causes serious and irreversible yield losses through shortening the economic lifespan of oil palms (Cooper et al., 2011). Losses due to Ganoderma disease on oil palm could be either direct or indirect, whereby the direct losses refer to the collapse or death of the palm, and indirect loss may be referred to the decline in fresh fruit bunches (FFB) weight and quality (Susanto et al., 2009).

Plants respond to pathogen attack or elicitor (biological control agents) treatments by activating different types of protective mechanisms aimed at preventing pathogen development and spreading (Malolepsza and Rozalska, 2005). Plants produce 
a wide range of antioxidant enzymes and defense mechanisms such as polyphenol oxidase (PPO), peroxidase (PO) and phenylalanine ammonia lysase (PAL) that protect plant cells from oxidative damage and infestation from phytopathogens. Antioxidant enzymes work synergistically with defense enzymes to promote the scavenging activity of reactive oxygen species (ROS) and induce plant resistance (Singh et al., 2011). The ROS also forms physical barriers at the infection site by the oxidative cross-linking of precursors during the biosynthesis of polymers such as lignin and suberin or through cross-linking of cell wall glycoproteins (Torres, 2010). These polymers could be directly toxic, resulting in degrading the cell walls of the plant pathogenic fungi and bacteria (Treutter, 2006). In addition, phenolic compounds also act as anti-microbials, structural barriers, growth inhibitors of invaders, modulators of pathogenicity and activators of plant defense genes (Rao et al., 2015). Trichoderma have the potential to attack plant pathogens and inhibit their growth; many reports have shown that Trichoderma induced local and systemic resistance in plants against a wide range of plant pathogens (Harman et al., 2004; Shoresh et al., 2010). Therefore, induced resistance ability in the palms may provide a reliable and sustainable alternative approach for the control of diseases caused by Ganoderma spp.

\section{MATERIALS AND METHODS}

\section{Planting Materials and Preparation of Soil Mixture}

Oil palm seedlings used in nursery trial studies were four-month old cultivar Deli dura $\times$ AVROS pisifera (Calix 600) purchased from Sime Darby Seeds and Agricultural Services Sdn Bhd, Banting, Selangor, Malaysia. Soil mixture was prepared at Ladang Dua, Faculty of Agricuture, Universiti Putra Malasyia (UPM), Serdang, Selangor, Malaysia and sterilised at $120^{\circ} \mathrm{C}$ for $90 \mathrm{~min}$. The soil mix was in a ratio of 3:2:1 (top soil:peat soil:sand). The sterilised soils were then placed into Panterra plastic garden pots [height $16 \mathrm{~cm}$, diameter $21 \mathrm{~cm}$ (top) and 14 $\mathrm{cm}$ (bottom)]. The seedlings were transferred to plastic pots containing sterilised soil mixture prior to artificial inoculation with $G$. boninense fully colonised rubber wood blocks (RWB) as described below from the original tray at nursery Ladang 15, Faculty of Agriculture, UPM and watered twice daily. The 15-15-15 NPK fertiliser was applied every two months as recommended until harvest (Nusaibah et al., 2017).

\section{Ganoderma Inoculum on RWB Preparation}

RWB of $6.0 \times 6.0 \times 6.0 \mathrm{~cm}$ in size were utilised for the current experiment and the preparation of
G. boninense (UPM 13) inoculum was carried out according to Nusaibah et al. (2016). Each RWB was placed into a heat-resistant polypropylene bag of 10.0 $x 32.0 \mathrm{~cm}$ and autoclaved at $1.40 \mathrm{~kg} \mathrm{~cm}^{-2}$ pressure, $121^{\circ} \mathrm{C}$ for $25 \mathrm{~min}$. After autoclaving, the blocks were left soaked in potato dextrose broth (PDB) overnight in basins. On the following day, the blocks were again placed in a heat-resistant polypropylene bag and $100 \mathrm{ml}$ of PDB was added to each bag. The bags were then tied with raffia strings and autoclaved for a second time under the mentioned conditions. Inoculum preparations were made by placing 10 plugs sized $6 \mathrm{~mm}$ from eight-day old mycelium cultures of $G$. boninense grown on potato dextrose agar (PDA) obtained using a core-borer onto each surface of the autoclaved RWB. Then, the bags were tied quickly and carefully to avoid contamination and incubated in the dark at $25 \pm 1^{\circ} \mathrm{C}$ for 10 to 12 weeks. Fully colonised and uncontaminated blocks were used for inoculation on the oil palm seedlings.

\section{Artificial Inoculation}

Fully colonised RWB with pathogenic $G$. boninense mycelium was placed horizontally at the centre of the pot. The seedlings were then placed on top of the blocks, ensuring that the roots will come in a direct contact with the inoculums and covered with the top soil. Detail of the treatments are laid out in Table 1.

\section{Preparation and Application of Trichoderma Conidial Suspension}

The Trichoderma spp. and G. boninense (UPM 13) used as the treatment and pathogen respectively (Table 1) were the culture collections of GanoLab, Department of Plant Protection, Faculty of Agriculture, UPM. These isolates were subcultured on PDA and incubated at $25^{\circ} \mathrm{C}$ for seven days. Subsequently, the seven-day old culture was harvested using $10 \mathrm{ml}$ of sterilised distilled water by gently scrubbing the colony surface with a glass rod. The plates were washed for the second time to harvest all the fungal cultures. Conidial suspension was passed through a sterilised cloth strainer to remove mycelia fragments and the filtrate for each Trichoderma species was utilised, namely Trichoderma

\section{TABLE 1. EXPERIMENTAL TREATMENT DESIGN}

\begin{tabular}{cl}
\hline Treatments & \multicolumn{1}{c}{ Descriptions } \\
\hline T1 & T. asperellum + G. boninense + plant \\
T2 & T. harzianum + G. boninense + plant \\
T3 & T. virens + G. boninense + plant \\
T4 & Mixture of T. asperellum + T. harzianum + \\
& T. virens + G. boninense + plant \\
T5 & Negative control (+ plant ) \\
T6 & Positive control G. boninense (+ plant $)$ \\
\hline
\end{tabular}


asperullum, Trichoderma harzianum and Trichoderma virens. One hundred $\mathrm{ml}$ of Trichoderma sp. spore suspension with a final concentration of $5 \times 10^{8}$ conidia/ml from each species used per seedling per treatment were drenched two weeks before artificial inoculation with G. boninense. As for the mixture treatment, $300 \mathrm{ml}$ of spore suspension containing spores from all the three Trichoderma species $\left(5 \times 10^{8}\right.$ conidia/ml for each species) were applied. Sterile distilled water was used in the positive control treatments.

\section{Experimental Design}

The nursery trial experiments were arranged in a randomised complete block design (RCBD) with six treatments and 10 replications.

\section{Disease Assessment}

Disease development was monitored based on a quantitative assessment measured as DI, which was expressed in percentage at intervals of months. DI was assessed based on foliar disease severity (chlorosis and necrosis of leaves, with or without presence of Ganoderma basidiocarp and dead plants). DI refers to the number of seedlings showing symptoms mentioned above in relation to the total number of seedlings assessed by the formula from Campbell and Madden (1990):

$$
\begin{aligned}
& \% \text { Disease } \\
& \text { incidence } \\
& \text { (DI) }
\end{aligned}=\left[\begin{array}{c}
\begin{array}{c}
\text { Number of } \\
\text { seedlings infected }
\end{array} \\
\begin{array}{c}
\text { Total number of } \\
\text { seedlings assessed }
\end{array}
\end{array}\right] \times 100
$$

\section{Percentage of Disease Reduction}

Percentage of disease reduction (DR) was also determined based on the following formula according to Bivi et al. (2016):

$$
\mathrm{DR}=\frac{\begin{array}{c}
\text { DI of positive control seedlings-DI } \\
\text { of treated seedlings }
\end{array}}{\text { DI of positive control seedlings }} \times 100
$$

\section{Foliar Disease Severity}

Meanwhile, the severity of foliar symptoms (\%) was assessed on a monthly basis according to Sariah and Zakaria (2000) using the formula:

Severity of foliar

symptoms $(\mathrm{SFS})=[(\mathrm{a} \times 1)+(\mathrm{b} \times 0.5) / \mathrm{c} \times 100]$

where, $a$ is the number of desiccated (browned/ wilted) leaves, $b$ is the yellowing leaves, $c$ is the total number of leaves, 1 is the index for desiccated leaves, and 0.5 is the index for yellowing leaves.

\section{Root and Bole Disease Severity}

At destructive sampling, the seedlings were dissected longitudinally to observe root and stem damage and the severity of the internal symptoms was visually assessed based on the proportion of root and bole tissues damaged by G. boninense. The estimation was based on the following scale in Table 2 (Nusaibah et al., 2017).

Disease severity (DS) for internal symptom of bole and root tissues was calculated based on the following formula derived from Liu et al. (1995) as follows:

$$
\mathrm{DS}_{\text {(internal) }}=\frac{\begin{array}{l}
\text { Number of seedlings in the rating } \times \\
\text { rating number } \times 100
\end{array}}{\begin{array}{l}
\text { Total number of seedling assessed } \times \\
\text { highest rating }
\end{array}}
$$

TABLE 2. SCALE USED TO SCORE DISEASE SEVERITY INDEX BASED ON ROOT AND BOLE TISSUES OF OIL PALM SEEDLINGS INOCULATED WITH Ganoderma boninense

\begin{tabular}{cl}
\hline Scale & Symptoms \\
\hline 0 & Healthy: no internal rot \\
1 & $20 \%$ rotting of tissues \\
2 & $20 \%$ to $50 \%$ rotting of tissues \\
3 & $>50 \%$ rotting of tissues \\
4 & $>90 \%$ rotting of tissues \\
\hline
\end{tabular}

\section{Assessment on the Plant Growth}

To evaluate the effect of Trichoderma spp. on oil palm seedlings growth in relation to disease development, plant height was measured on a monthly basis throughout the in vivo trial. The plant height was measured from ground level to the tip of the tallest leaf by placing a steel measuring tape alongside the plant. The stem girth was also measured monthly using an electronic digital caliper, and for the effect of Trichoderma spp. on leaf index, destructive samples were collected on a monthly basis and the LI-3100 Area meter (LI-COR Inc. Lincoln, Nebraska, USA) was used to measure the leaf area index.

\section{Shoot and Root (fresh and dry weight)}

In order to determine the effect of Trichoderma spp. on the general health of plant in relation to disease and plant growth, six months after transplanting and treatment application (at the end of experiment), the plants fresh and dry weights were measured for all treatments. Plants were harvested for the shoots and roots by uprooting the plants and cutting the shoots from the roots. The shoots and roots were dried in an oven (Memmert, Loading Modell 100 - 800, Schwabach, Germany) at $70^{\circ} \mathrm{C}$ for three days to obtain a constant weight. 


\section{Statistical Analysis}

Statistical analysis of the data was carried out via analysis of variance (ANOVA) using the SAS software [SAS 9.4 Version Institute Inc. Cary, NC, USA]. The means were separated using Tukey's multiple range tests at $p<0.05$, where the F-value was significant.

\section{Isolation of Ganoderma boninense from Infected Oil Palm Roots after Six Months of Incubation}

Harvested primary root samples from each treatment were subjected to incubation on PDA for pure culture isolation purpose. Freshly harvested roots were brought back to the laboratory and washed under running tap water to remove all sand particles. Then, the roots were sterilised by soaking them in $75 \%$ ethanol for $3 \mathrm{~min}$, followed by distilled sterile water for $3 \mathrm{~min}$ and tapped on sterile filter paper until water from the root surface was fully absorbed prior to incubation on PDA plates. After five days of incubation, single colonies were transferred to new PDA plates until pure cultures were confirmed via morphological identification. $G$. boninense inoculated in the nursery trial were successfully isolated from the infected primary roots. The pure cultures obtained were then subjected to DNA extraction and molecular identification.

\section{Molecular Detection of Ganoderma Disease Infection}

Extraction method for total DNA was done according to the manual provided in Qiagen DNeasy Plant Mini Kit with a slight modification according to Nusaibah et al. (2011). Polymerase chain reaction (PCR) amplification of Ganoderma boninense treated oil palm root genomic DNA was performed using the Ganoderma specific primers; Gan1: 5' - TTG ACT GGG TTG TAG CTG - $3^{\prime}$ and Gan2: 5' - GCG TTA CAT CGC AAT ACA - 3' (Utomo and Niepold, 2000) and a PCR master mix was prepared using QIAGEN Hotstar-Taq Plus PCR Master Kit (QIAGEN, Germany) and according to the manufacturer's instructions. The PCR protocol used started with denaturation for $2 \mathrm{~min}$ at $95^{\circ} \mathrm{C}$. This was followed by 35 cycles of denaturation for $1 \mathrm{~min}$ at $94^{\circ} \mathrm{C}$, annealing for $30 \mathrm{~s}$ at $60^{\circ} \mathrm{C}$ and extension for $2 \mathrm{~min}$ at $72^{\circ} \mathrm{C}$. The final step of extension was carried out for $10 \mathrm{~min}$ at $72^{\circ} \mathrm{C}$, before it was maintained at $4^{\circ} \mathrm{C}$. Later, $5 \mu \mathrm{l}$ of loading dye was pipetted to each tube of PCR product prior to the gel electrophoresis step. The amplified products were analysed by electrophoresis in $1.7 \%$ agarose in $1 \times \mathrm{TBE}$ at $65 \mathrm{~V}$ for $80 \mathrm{~min}$ and visualised using Etidium bromide (0.5 $\mu \mathrm{g} \mathrm{ml}^{-1}$ ) for 20-30 min before visualising under a UV transilluminator $\left(\operatorname{BioRad}^{\circledR}\right)$.
Preparation of Crude Extract for Peroxidase (PO) and Polypherol Oxidase (PPO) Assay

Leaf crude extract was prepared according to the method described by Samatha et al. (2012). A total of $0.25 \mathrm{~g}$ of fresh leaves was harvested on a monthly basis; each of the samples was ground in a chilled mortar and pestle by adding liquid nitrogen until a fine powder was obtained. The ground samples were transferred to $2 \mathrm{ml}$ eppendorf tubes and kept in ice. The samples were then treated with $250 \mu$ l of cold $0.05 \mathrm{M}$ sodium acetate buffer ( $\mathrm{pH} 5)$. About $1.5 \mathrm{mg}$ of polyvinyl pyrrolidone (PVP) was added to the mixture and centrifuged for $20 \mathrm{~min}$ at 14000 $\mathrm{rpm}\left(4^{\circ} \mathrm{C}\right)$. After centrifugation, the supernatant for each of the samples was collected and used for PO and PPO determinations.

\section{Determination of $\mathrm{PO}$}

About $50 \mu$ of the enzyme extract was transferred into a $2 \mathrm{ml}$ tube containing $750 \mu \mathrm{l}$ of reaction substrate $[80 \mu \mathrm{l}$ of $0.1 \mathrm{M}$ sodium phosphate buffer ( $\mathrm{pH}$ 6), followed by an addition of $250 \mu \mathrm{l}$ of $1 \mathrm{mM}$ hydrogen peroxide]. Another $500 \mu \mathrm{l}$ of guaicol was added to the tube and the mixture was incubated at room temperature $\left(26^{\circ} \mathrm{C}-28^{\circ} \mathrm{C}\right)$ for 30 $\mathrm{min}$. A change in absorbance measured at $470 \mathrm{~nm}$ at a $3 \mathrm{~s}$ interval for $1 \mathrm{~min}$ was recorded after inserting the cuvette in a UV spectrophotometer. The blank was prepared from the reaction substrate without addition of the extract as a control (Kokkinakis and Brook, 1979).

\section{Determination PPO}

Determination of PPO was verified with the change in colour intensity of pyrrol products. The reaction mixture comprised of $50 \mu \mathrm{l}$ of enzyme extract from different samples and placed in a $2 \mathrm{ml}$ tube containing $750 \mu \mathrm{l}$ of $0.2 \mathrm{M}$ sodium acetate buffer $(\mathrm{pH} 5)$ at $4^{\circ} \mathrm{C}$. Another $100 \mu \mathrm{l}$ of $0.02 \mathrm{M}$ pyrogallol was added to the reaction mixture. The activity was expressed at $410 \mathrm{~nm}$ absorbance. The blank was prepared from the reaction substrate without adding the extract (Kokkinakis and Brook, 1979).

\section{Determination of Total Phenolic Content (TPC)}

TPC of the leaves was examined using the method by Slinkard and Singleton (1977). TPC was expressed as Gallic acid equivalents (GAE) $\mathrm{g}^{-1}$ of the leaves. The activities of PO, PPO and TPC were expressed as changes in absorbance unit $\mathrm{g}^{-1}$ of plant tissue according to the formula described by Kokkinakis and Brook (1979).

Unit $\mathrm{g}^{-1}$ tissue $=\frac{\text { Optical density } \times \text { dilution factor }}{\mathrm{g} \text { of tissue used in the assay }} \times 100$ 
where, optical density $=$ the absorbance of spectrophotometer, dilution factor $=10, g=$ the amount of tissue used.

\section{RESULTS}

Effect of Trichoderma spp. on Basal Stem Rot Disease Suppression in Oil Palm Seedlings

DS analysis based on the foliar and bole demonstrated that the oil palm seedlings treated with $\mathrm{T} 4$ in the nursery experiment have significantly $(p<0.05)$ reduced the percentage of DSI caused by $G$. boninense. Thus, the mixture application of Trichoderma spp. (T4) has established successful disease suppression. The positive control treatment suffered the highest damage based on the foliar symptoms and bole rot (with bole necrotic lesions $>50 \%$ ). The foliar disease symptoms were significantly reduced by $83.03 \%$ in $\mathrm{T} 4$, followed by $81.49 \%, 78.78 \%, 74.57 \%$ in $\mathrm{T} 2, \mathrm{~T} 1$, and $\mathrm{T} 3$, respectively. Similarly, the mixture treatment had significantly reduced bole damage by $89.16 \%$ in T4 (Figure 1), while the negative control (T5) remained healthy throughout the experimental period.

The percentages of disease reduction calculated based on both foliar and bole symptoms are shown on Table 3. Application of the Trichoderma spp. mixture acted as the most effective treatment in suppressing Ganoderma disease foliar symptoms with $83 \%$ DR percentage. Meanwhile, T1, T2 and T3 were also effective with the foliar DR of $78.7 \%$, $81.5 \%$ and $74.1 \%$, respectively. However, the lowest bole symptom DR was $78.6 \%$ in T1 treatment. In addition, the percentage of DI was assessed as in Figure 2. The highest percentage of DI was found in T6 (80\%), while the lowest was found in T4 $(20 \%)$ at six months after inoculation.

\section{国 FDS BDS}

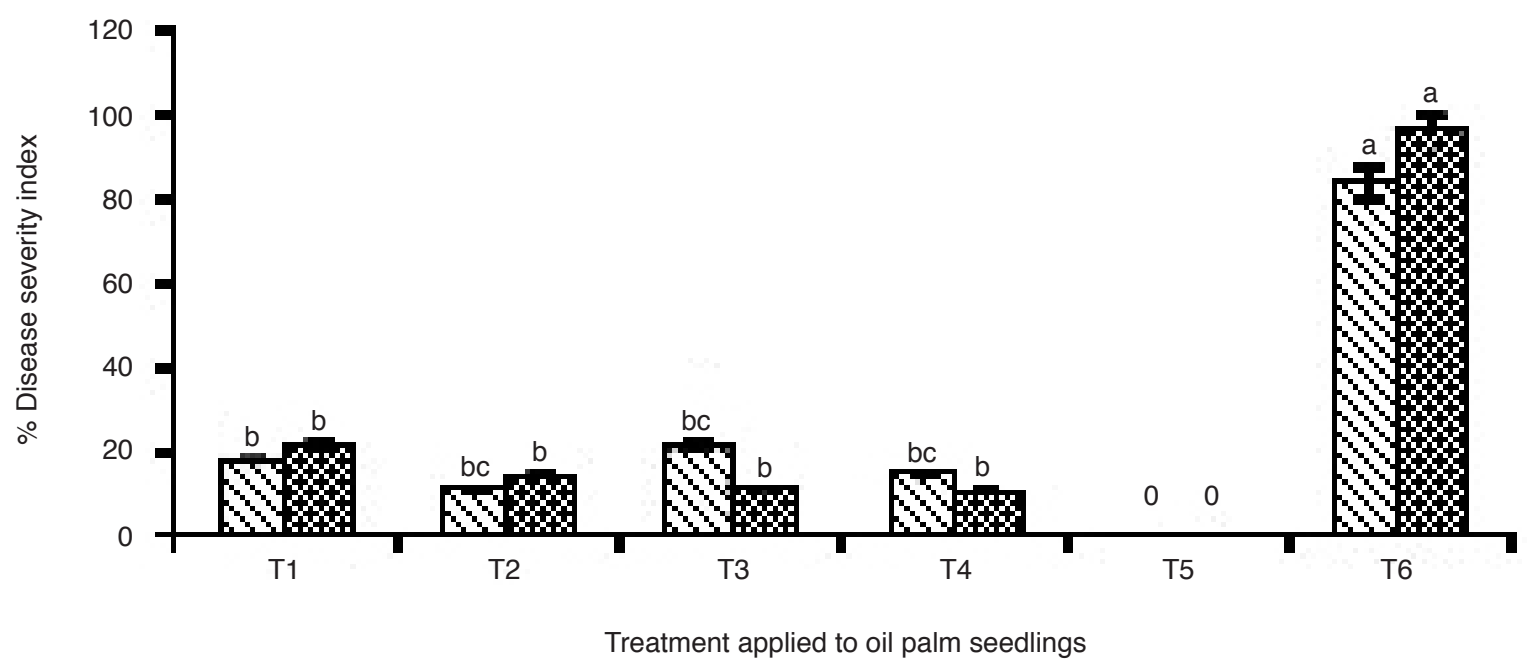

Note: FDS - foliar disease symptom. BDS - Bole disease symptom.

Figure 1. Foliar and bole disease severity index assessed after 24 weeks of inoculation period. Means ( $p \leq 0.05$ ) with the same letter are not significantly different by Tukey's studentised range (HSD) test. Vertical bar represents standard error.

TABLE 3. PERCENTAGE OF Ganoderma DISEASE REDUCTION ON DIFFERENT TREATMENTS AT SIX MONTHS AFTER ARTIFICIAL INOCULATION CALCULATED BASED ON NEGATIVE CONTROL TREATMENT

\begin{tabular}{ccc}
\hline Treatment & $\begin{array}{c}\text { Foliar symptoms } \\
\text { reduction (\%) }\end{array}$ & $\begin{array}{c}\text { Bole symptoms } \\
\text { reduction (\%) }\end{array}$ \\
\hline T1 (T. asperellum + G. boninense) & 78.7 & 78.6 \\
T2 (T. harzianum + G. boninense) & 81.5 & 85.4 \\
T3 (T. virens + G. boninense) & 74.7 & 89.1 \\
T4 T. asperellum + T. harzianum + & 83.0 & 89.4 \\
T. virens + G. boninense & & \\
\hline
\end{tabular}




\section{Effect of Trichoderma spp. Mixture on the Palm's Vegetative Growth}

Trichoderma spp. treatments promoted the growth of oil palm seedlings (Table 4). The effect of Trichoderma spp. mixture on oil palm seedlings growth was assessed by measuring the number of plant growth parameters at six months post inoculation (mpi). The plant height and stem girth were significantly increased by $28.33 \mathrm{~cm}$ and $5.95 \mathrm{~cm}$ respectively in $\mathrm{T} 4$, compared to the positive control seedlings in T6. The dried shoot and root tissue weight also increased by $6.53 \mathrm{~g}$ and $2.69 \mathrm{~g}$ respectively in T4. The leaf area index was significantly increased by 132.37 as compared to the positive control. The mixture of Trichoderma spp. treatment exhibited a significant effect on plant height, stem girth, leaf area index and seedlings biomass.

\section{Detection of Pathogenic Ganoderma and Trichoderma spp. from Harvested Roots}

To confirm disease establishment and the presence of biological control agents applied in each treatment, DNA amplification was applied to detect the microbes involved. Harvested primary roots of each treatment were incubated on PDA plates to yield the respective fungi, namely G. boninense and Trichoderma spp. These cultures were subcultured until pure cultures were obtained and then subjected to DNA extraction.

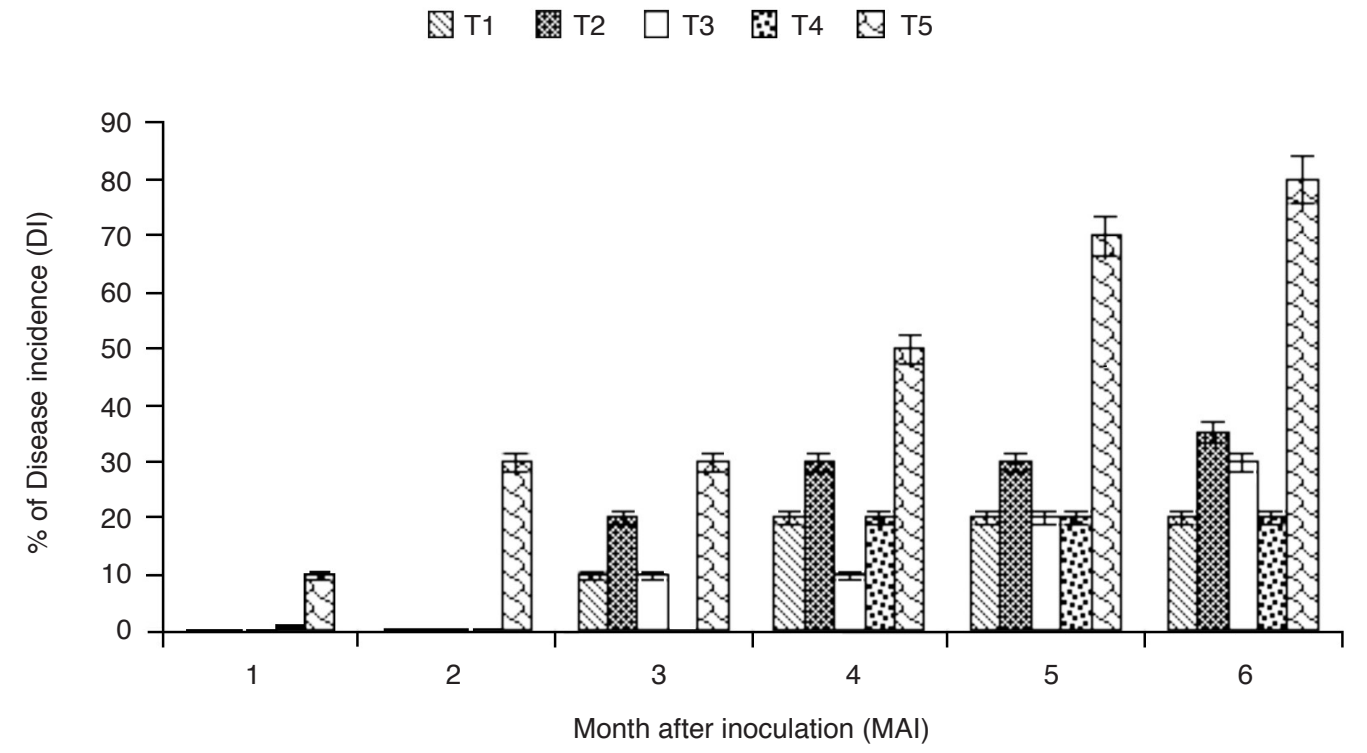

Note: T1 - T. asperellum + G. boninense; T2 - T. harzianum + G. boninense; T3 - T. virens + G. boninense; T4 - T. asperellum + T. harzianum + T. virens + G. boninense mixture and T6 - positive control (G. boninense).

Figure 2. Percentage of disease incidence in oil palm seedlings inoculated with Ganoderma boninense and treated with Trichoderma spp. (values are means of 10 replications; vertical bars are error bar, $p \leq 0.05$ ).

TABLE 4. EFFECTS OF Trichoderma spp. TREATMENTS MIXTURE ON PALM'S VEGETATIVE GROWTH PARAMETER AT SIX MONTH POST INOCULATION

\begin{tabular}{|c|c|c|c|c|c|}
\hline Treatment & \multicolumn{5}{|c|}{ Seedling growth parameters } \\
\hline $\mathrm{T} 1$ & $68.25 \pm 1.58^{\mathrm{ab}}$ & $17.65 \pm 1.17^{\mathrm{a}}$ & $288.30 \pm 2.57^{b c}$ & $12.70 \pm 0.97^{\mathrm{ab}}$ & $4.27 \pm 0.36^{\mathrm{ab}}$ \\
\hline $\mathrm{T} 2$ & $65.62 \pm 2.23^{b c}$ & $16.92 \pm 1.31^{\mathrm{a}}$ & $303.17 \pm 1.96^{\mathrm{bc}}$ & $11.5 \pm 0.38^{\mathrm{ab}}$ & $4.23 \pm 0.57^{\mathrm{ab}}$ \\
\hline T3 & $62.85 \pm 2.82^{\mathrm{c}}$ & $16.44 \pm 1.48^{\mathrm{a}}$ & $312.77 \pm 3.98^{\mathrm{ab}}$ & $13.0 \pm 1.79^{\mathrm{ab}}$ & $4.17 \pm 0.93^{\mathrm{ab}}$ \\
\hline $\mathrm{T} 4$ & $69.86 \pm 2.73^{a}$ & $17.72 \pm 1.42^{\mathrm{a}}$ & $361.48 \pm 2.06^{\mathrm{a}}$ & $14.1 \pm 1.06^{\mathrm{a}}$ & $5.23 \pm 0.65^{\mathrm{a}}$ \\
\hline
\end{tabular}

Note: Means with the same letter are not significantly different by Tukey's test at 5\% level of significance. T1 - Trichoderma asperellum + Ganoderma boninense; T2 - Trichoderma harzianum + Ganoderma boninense; T3 - Trichoderma virens + Ganoderma boninense; T4 - T. asperellum + T. harzianum + T. virens + G. boninense mixture; T5 - negative control; T6 - positive control (only Ganoderma boninense). 
PCR was carried out by amplifying the DNA of these isolates via Ganoderma and Trichoderma genus specific marker sets respectively (Figure 3), Gan1: 5' - TTG ACT GGG TTG TAG CTG - 3', Gan2: 5' - GCG TTA CAT CGC AAT ACA - 3', TVPF: 5'CCGCCGGAGGACCAACCAA3' andTVPR5'GACAGGCATGCCCGCCAGA3'. These markers successfully amplified all the isolated microbes used in this study and the sequences were identified as G. boninense (UPM13) (167 bp) (Figure 3) and Trichoderma spp. (245 bp) (Figure 4).

\section{Polyphenol Oxidase Activity}

The results indicated that all the three Trichoderma spp. had the ability to induce defense enzymes in Trichoderma treated oil palm seedlings and the Trichoderma spp. mixture treatment displayed the maximum PPO activities among all the treatments. At one mpi with G. boninense and treated with Trichoderma spp., the PPO activity significantly increased as compared to the negative and positive controls. PPO activity in all treatments reached a maximum peak at three and four mpi, and a decrease was recorded in the subsequent month. The increase of this enzyme was greater in oil palm seedlings treated with Trichoderma alone or in combination with $G$. boninense than oil palm seedlings inoculated with $G$. boninense alone. In addition, T4 (mixture of Trichoderma spp.) induced significantly higher levels of disease infestations in oil palm seedlings as compared to the controls based on DS and DI (Figure 5).

\section{PO activity}

The results indicated that $\mathrm{PO}$ activity in Trichoderma spp. treated oil palm seedlings varied from 72.25 to $167.89 \mathrm{U} \mathrm{g}^{-1}$ tissue. There was a significant difference in the activity of PO between Trichoderma spp. treatments (Figure 6). The maximum PO was detected in T1 (167.89 $\mathrm{U} \mathrm{g}^{-1}$ tissue) at four mpi, whereas the minimum activity was from T5 (72.2589 $\mathrm{U} \mathrm{g}^{-1}$ tissue) at one mpi. Based on the overall results obtained, T. asperellum was identified as the

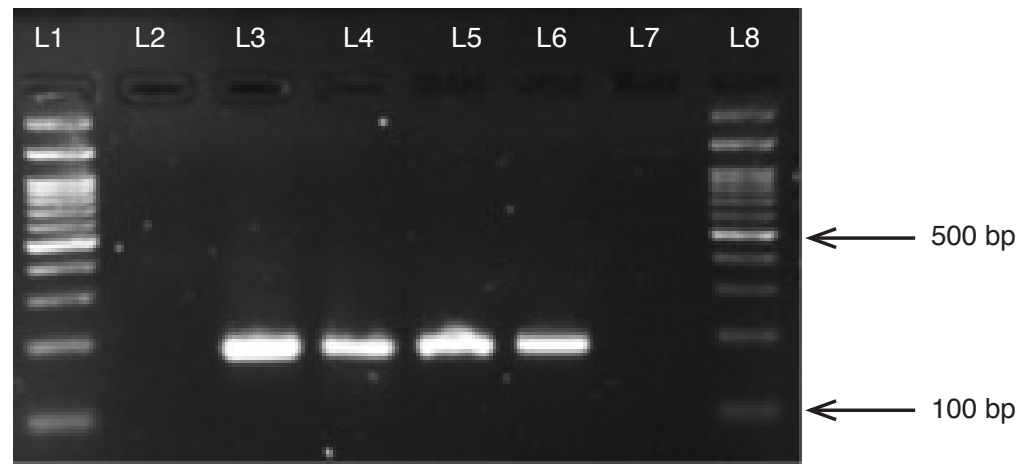

Figure 3. Polymerase chain reaction amplification products with the size of 167 bp were generated by Ganoderma genus specific primer sets, Gan 1 and Gan 2. Lane 1 and 8: 100 bp ladder; Lane 2: negative control; Lane 3: Ganoderma boninense (UPM13) isolated from treatment -T1= treated with Trichoderma asperellum + Ganoderma boninense + plant; Lane 4: Ganoderma boninense (UPM13) isolated from treatment-T2= treated with Trichoderma harzianum + Ganoderma boninense + plant; Lane 5: Ganoderma boninense (UPM13) isolated from treatment - T3= treated with Trichoderma virens + Ganoderma boninense + plant; Lane 6: Ganoderma boninense (UPM13) isolated from treatment -T6= Positive control (only Ganoderma boninense) + plant], Lane 7: Aspergillus niger (control).

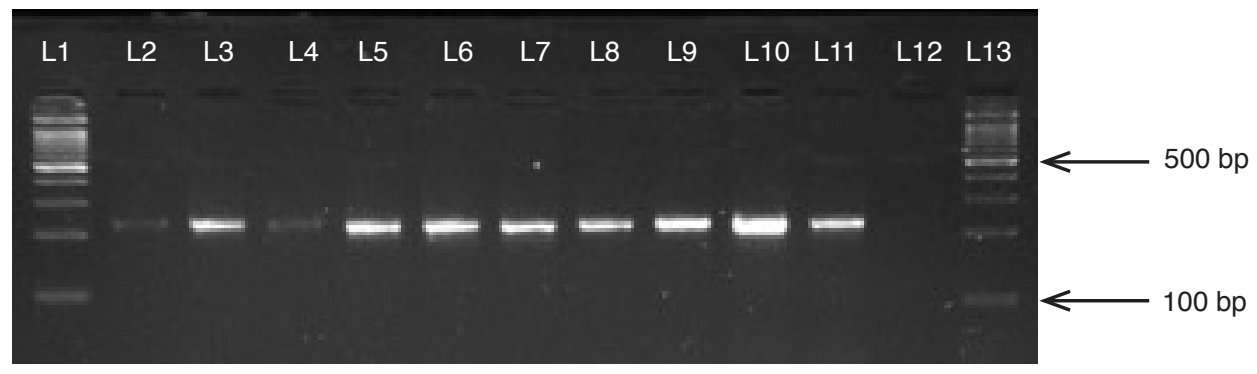

Figure 4. Polymerase chain reaction amplification products with 245 bp generated by Trichoderma genus specific primer sets, TvPF and TvPR. Lane 1 and 13: $100 \mathrm{bp}$ ladder; Lane 2, 3 and 4: Trichoderma asperellum isolates isolated from treatment -T1=treated with Trichoderma asperellum + Ganoderma boninense + plant; Lane 5, 6 and 7: Trichoderma harzianum isolates isolated from treatment - T2 $=$ treated with Trichoderma asperellum + Ganoderma boninense + plant; Lane 8, 9 and 10: Trichoderma virens isolates isolated from treatment -T2 = treated with Trichoderma asperellum + Ganoderma boninense + plant; Lane 11: Aspergillus niger (control); Lane 12: negative control. 


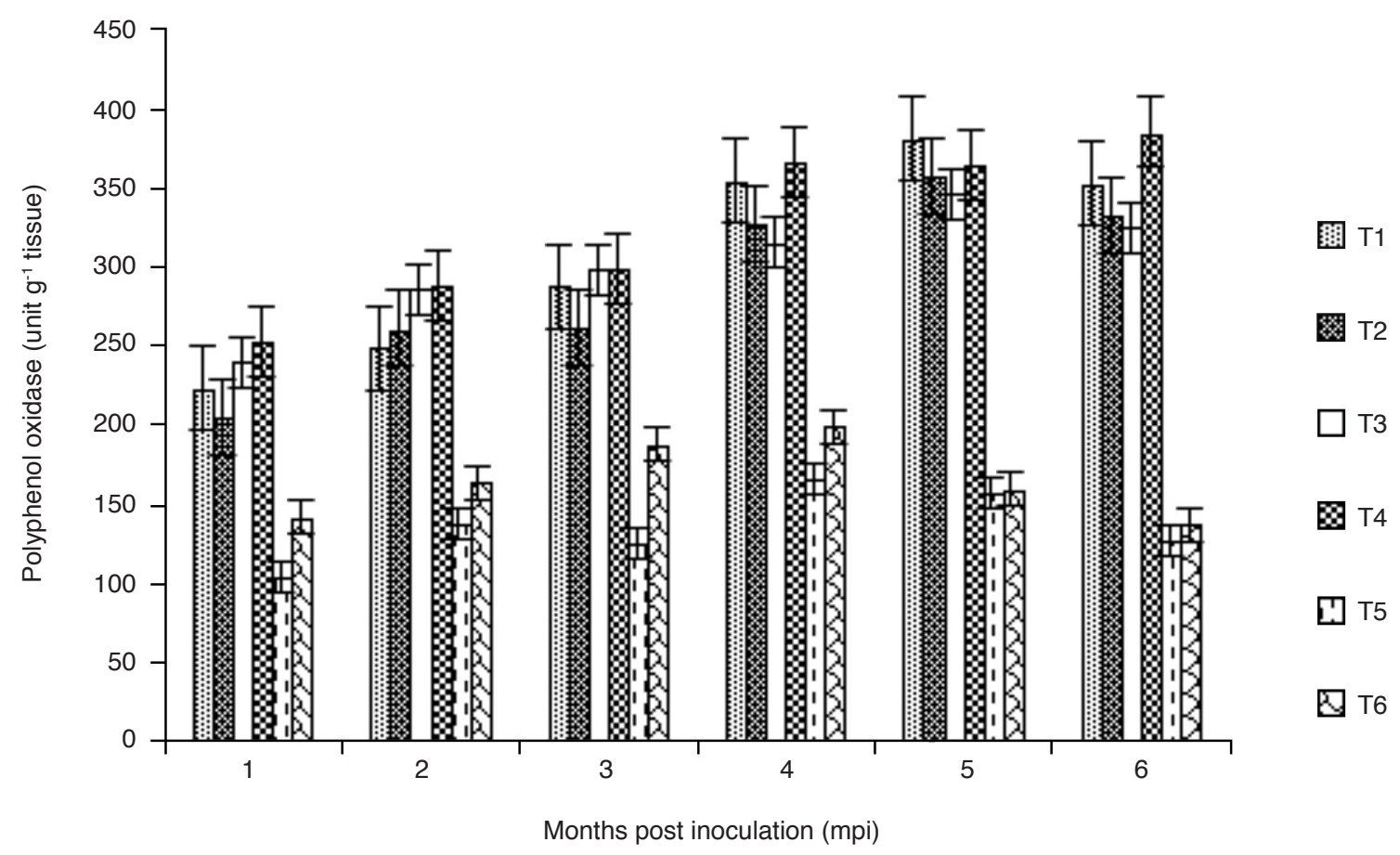

Note: T1 - Trichoderma asperellum + Ganoderma boninense; T2 - Trichoderma harzianum+Ganoderma boninense; T3 - Trichoderma virens + Ganoderma boninense; T4 - T. asperellum + T. harzianum + T. virens + G. boninense; T5 - negative control; T6 - positive control (only Ganoderma boninense).

Figure 5. Effect of Trichoderma spp. treatments on polyphenol oxidase activity of oil palm seedlings inoculated with Ganoderma boninense. Values are means of five replications and differences between the means are separated by Tukey's test at 5\% level of significance, bars = standard error

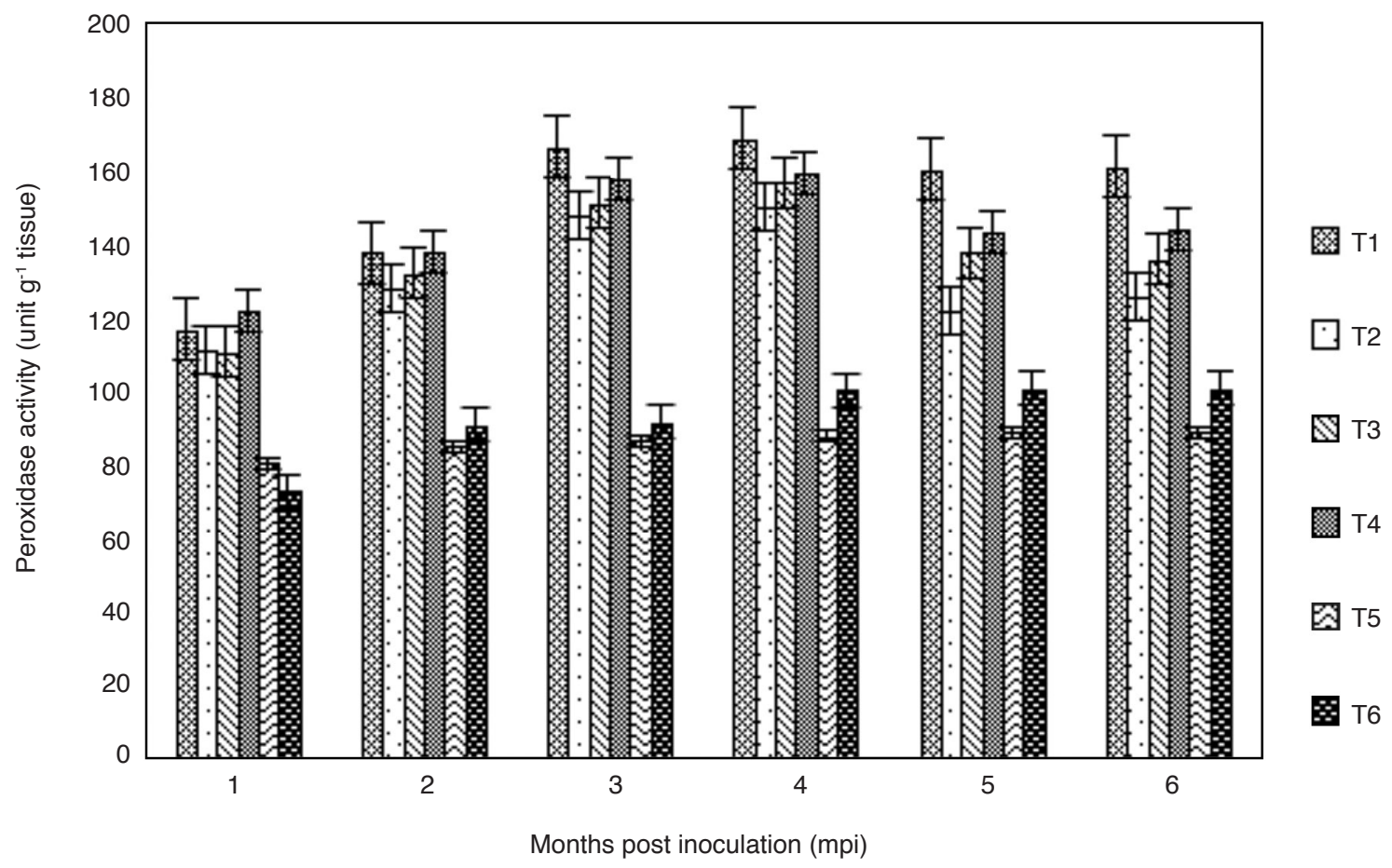

Note: T1 - Trichoderma asperellum + Ganoderma boninense; T2 - Trichoderma harzianum + Ganoderma boninense; T3 - Trichoderma virens + Ganoderma boninense; T4 - T. asperellum + T. harzianum + T. virens + G. boninense; T5 - negative control; T6 - positive control (only G. boninense).

Figure 6. Effect of Trichoderma spp. treatments on peroxidase activity on oil palm seedlings inoculated with Ganoderma boninense. Values are means of five replications and difference between the means are separated by Tukey's test at 5\% level of significance, bars = standard error. 
species that triggered the most in the induction of oil palm PO activity. In general, Trichoderma treatments were able to produce an inducible PO defense enzyme that was higher than the untreated control treatments.

\section{Estimation of Total Phenolic Content from Roots of Oil Palm Seedlings}

The accumulations of total phenolic content for various treatments in the $G$. boninense infected oil palm seedling roots were recorded (Figure 7). The positive control (T6) showed the lowest accumulation of total phenolic content $(18.7 \mathrm{mg}$ $\mathrm{g}^{-1}$ ), while the mixture of Trichoderma spp. (T4) recorded the highest accumulation $\left(49.6 \mathrm{mg} \mathrm{g}^{-1}\right)$ in the seedling root at harvest. Among the various treatments tested, T4 was found to be the best treatment to increase the total phenolic content in oil palm seedling root infected with $G$. boninense. T1 $\left(44.08 \mathrm{mg} \mathrm{g}^{-1}\right)$, T2 (46.25 $\left.\mathrm{mg} \mathrm{g}^{-1}\right)$, and T3 (42.6 mg g $\left.{ }^{-1}\right)$ also showed potential for increasing total phenolic content to suppress G. boninense activity.

\section{DISCUSSION}

The present study determines the efficacy of Trichoderma spp. mixture on the control of G. boninense infection in oil palm seedlings.
This work provided evidence that Trichoderma spp. mixture effectively suppressed BSR disease infestation, induced resistance and promoted oil palm seedling vegetative growth. The use of beneficial microbes in crop protection has greatly increased in the recent years. Trichoderma spp. are among the most promising fungi towards the development of sustainable agricultural production (Mokhtar and Aid, 2013; Bashan et al., 2014). Trichoderma spp. demonstrated high potentials as a biological control of Ganoderma infection in oil palm (Sariah et al., 2005; Sundram et al., 2008). Naher et al. (2014) also reviewed that T. harzianum and T. virens could strongly inhibit the growth of G. boninense in an in vitro trial. However, it was noted that Trichoderma could only protect the palms at a very early stage of Ganoderma infection, and is not able to cure severely infected palms (Abdullah et al., 2003).

The application of Trichoderma spp. mixture provided the preventive effects that significantly reduced the disease symptoms established in oil palm seedlings. Furthermore, the mixture application tends to portray synergistic effects that enhanced the efficacy of Trichoderma spp. in the biological control of G. boninense in oil palm seedlings. In all Trichoderma treated seedlings, higher disease suppression led to a corresponding increase in fresh and dry shoot weights as well as an increase in root weight (fresh and dry). The increase in palm growth and stimulation of the defense system due

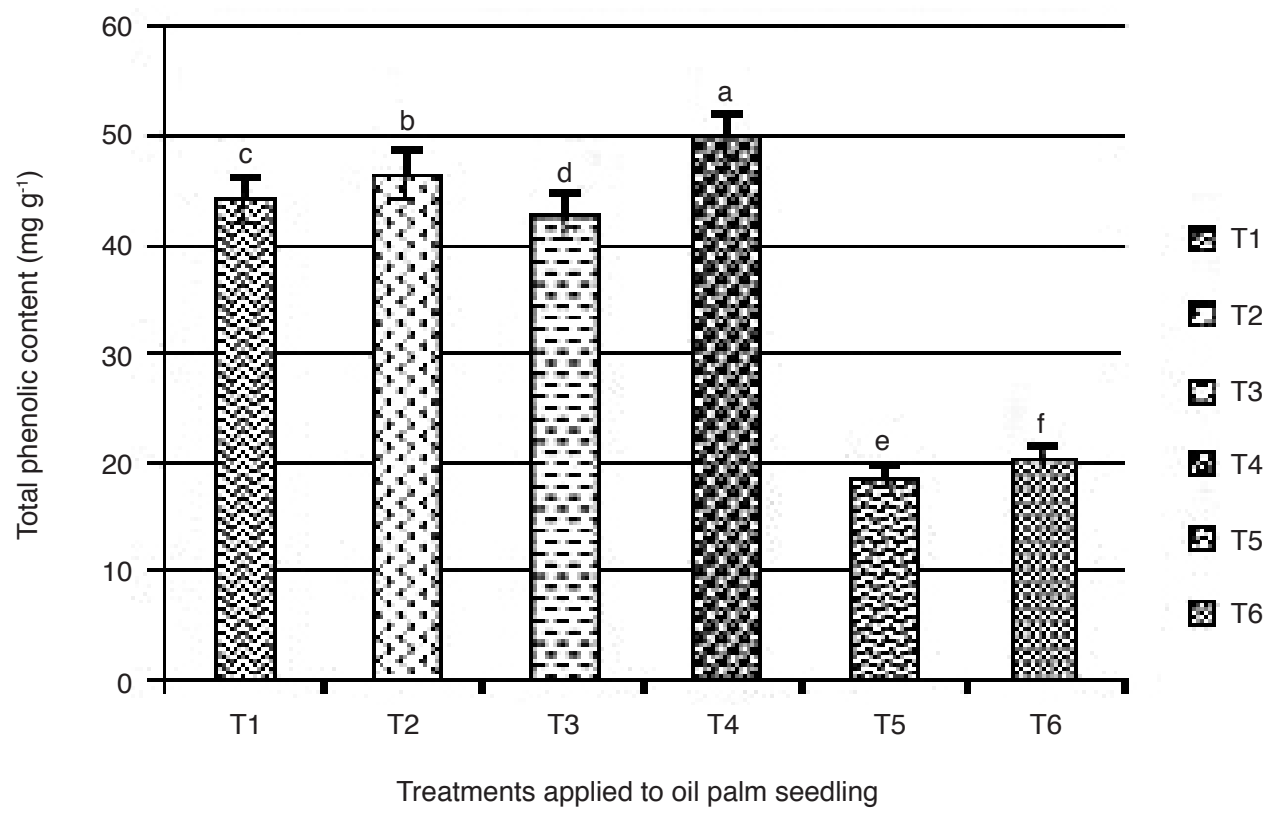

Note: T1 - Trichoderma asperellum + Ganoderma boninense; T2 - Trichoderma harzianum + Ganoderma boninense; T3 - Trichoderma virens + Ganoderma boninense; T4 - T. asperellum + T. harzianum + T. virens + G. boninense; T5 - negative control; T6 - positive control (only G. boninense).

Figure 7. Total phenolic content [expression as 4-hydroxybenzoic acid (mg) equivalent to root weight $(\mathrm{g})$ ] in oil palm seedling root at six months after inoculation and treatment. Means represented with the same letter in a column are not significantly different by Tukey's Test at 5\% level of significance, bars represent standard error. 
to seedling treatment with Trichoderma spp. were in concomitant with the previous research findings (Hermosa et al., 2013; Martinez-Medina et al., 2014; Saravanakumar et al., 2016). Increase in plant vegetative growth treated with Trichoderma spp. has been reported on arable crops such as maize (Zea mays) (Harman et al., 2004), wheat (Triticum aestivum) (Shivanna et al., 1996), and cotton (Shanmugaiah et al., 2009). Rinu et al. (2014) also reported on the growth enhancement of legume crops after the application of Trichoderma gamsii. Likewise, in tree crops such as cocoa, significant increases in fresh shoot weight, root weight and plant height were observed when compared with the control seedlings after a treatment period of five months in a nursery with T. asperellum application (Tchameni et al., 2011). In addition, increases in Pinus radiate (coniferous evergreen tree) seedling stem diameter, height and dry weight by $30 \%$ in nurseries were reported when treated with Trichoderna spp. mixtures (Minchin et al., 2006).

Mixtures were reported to give a greater bioactivity than single Trichoderma spp. applied to crops in terms of growth promotion and enhanced immunity against diseases (Singh et al., 2011). A work by Rudresh et al. (2005) demonstrated that a mixture of three Trichoderma strains [T. viride (PDBCTV 32), T. virens (PDBCTV 12), and T. harzianum (PDBCTH 10)] applied to chickpeas in a nursery trial yielded a significant increase in the number of branches/ plant, plant height and increased uptake of nitrogen and maximum shoot and root phosphorus uptake. In addition, positive results in field trials also led to increased branch number, plant height, total biomass, and nitrogen uptake to the shoot and root (Rudresh et al., 2005). Mixture of Trichoderma spp. with each other or other antagonist microbes may result in a decrease of antagonistic effects or may otherwise lead to a synergistic effect that will increase the efficacy of disease suppression (Robinson et al., 2009). Mixture of two T. harzianum strains showed more synergistic effect against Rhizoctonia solani (Yobo et al., 2011) which could be due to the fact that different Trichoderma species produce different toxic substances (gliotoxin) that might help to increase the establishment of T. harzianum in the soil.

Our data also revealed that the mixture of Trichoderma spp. treatment in oil palm improved and increased PPO, PO and TPC activities significantly in response to $G$. boninense infection. In addition, the PPO and PO in positive control (T6) were observed to be higher compared to the negative control (T5), and these responses could be the systemic defense demonstrated by the palm itself to counter Ganoderma infection. Unfortunately, the increasing trend in PPO dropped gradually from 4 mpi onwards, exhibiting the palms' inability to fight against the stronger counter-attack by G. boninense.
Thus, the treatments with Trichoderma aided the palms tremendously by increasing the levels of $\mathrm{PO}$ and PPO, even with the stronger counter attack by the pathogenic Ganoderma. These findings are supported by the earlier observation by Singh et al. (2011), who reported on an increased activity of phenylalanine-ammonia lyase and peroxidase in chickpea when the plants were treated with Trichoderma strain, Pseudomonas fluorescens and a Rhizobia strain RL091 in a mixture under the stress of Sclerotium rolfsii.

In a study by Latha et al. (2009), tomato seeds pre-treated with Bacillus subtilis and P. fluorescens demonstrated reduction in disease incidence of early leaf blight that was correlated with increased accumulation of PPO and PO enzymes. A microbial mixture consisting of Pseudomonas aeruginosa, Mesorhizobium spp. and T. harzianum was shown to induce defense responses against $S$. rolfsii in chickpea. Co-inoculation of Azospirillum sp. and $P$. aeruginosa was found to have synergistic effects on yield and suppression of root rot disease caused by Rhizoctonia bataticola (Marimuthu et al., 2013). Enhanced activation of phenylalanine-ammonia lyase pathway leading to a sudden increase in concentration of phenolics was achieved when plants were inoculated with a mixture of beneficial microbes (Singh et al., 2011). Cyanobacteria consortia Anabaena sp., Anabaena azotobacter biofilm and Providencia sp. elicited defense responses in a hybrid maize, leading to enhanced activity of defense enzymes such as PPO, PO and PAL in the maize roots, which also showed a positive correlation with increased crop vigor and yields (Prasanna et al., 2013). Similarly, systemic resistance was enhanced due to a high accumulation of defense enzyme in response to Ralstonia solanacearum challenged in tomatoes (Vanitha et al., 2009). The data obtained also demonstrated a synergistic combination of the Trichoderma spp. which triggered a higher phenolic compound accumulation in oil palm seedlings compared to single species application. Phenolic compounds in plants and their synthesis in response to infection have been associated with plant resistance (Nikraftar et al., 2013). These compounds accumulated in the plant cell wall in a salicylic acid (SA) dependent pathway (Alonso-Ramirez et al., 2014) and by releasing important anti-fungal compounds, which led to the resistance responses in plants. In addition, phenolic compounds are oxidised by other compounds like PO to form more toxic compounds, like quinines, which are directly toxic to fungal pathogens (Gogoi et al., 2001).

\section{CONCLUSION}

Based on the findings of this study, we concluded that the mixture of Trichoderma spp. could help in 
controlling BSR disease in oil palms. For a better control and prevention of G. boninense infestation, mixture of Trichoderma spp. could be applied at the nursery stage for a minimum of three months prior to seedlings transplant to the field to enable Trichoderma spp. to colonise the root zones. This may prevent soil-borne fungal pathogens, at the same time enhance the palm growth and improve plant health. Post inoculation demonstrated that the oil palm seedlings responded well to Trichoderma treatment by inducing systemic and localised resistances due to G. boninense infection and caused significant changes in the host plants in terms of PPO, PO and total phenolic content. These mechanisms may help in developing resistance in oil palm seedlings, thus protecting them from G. boninense infection.

\section{ACKNOWLEDGEMENT}

The authors acknowledge the financial support from UPM under Putra Grant (vote No. 9426000). The authors also would like to thank the staff of Department of Plant Protection, Faculty of Agriculture, UPM whom had contributed guidance and assistance in completing the current project.

\section{REFERENCES}

ABDULLAH, F; ILIAS, GN M; NELSON, M;IZZATI, $\mathrm{N}$ and YUSUF, K U (2003). Disease assessment and the efficacy of Trichoderma as a biocontrol agent of basal stem rot of oil palms. Science Putra, 12: 31-33.

ALONSO-RAMIREZ, A; POVEDA, J; MARTÍN, J I; HERMOSA, R; MONTE, E and NICOLÁS, C (2014). Salicylic acid prevents Trichoderma harzianum from entering the vascular system of the roots. Molecular Plant Pathology, 15(8): 823-831.

BASHAN, Y; DE-BASHAN, L E; PRABHU, S R and HERNANDEZ, J P (2014). Advances in plant growth-promoting bacterial inoculant technologyFormulations and practical perspectives (19982013). Plant and Soil, 10: 4-36.

BIVI, R; PAIKO, A S; KHAIRULMAZMI, A; AKHTAR, MS and IDRIS, AS (2016). Control of basal stem rot disease in oil palm by supplementation of calcium, copper, and salicylic acid control of basal stem rot disease in oil palm by supplementation of calcium. The Plant Pathology J., 10: 1-11.

CAMPBELL, C L and MADDEN, L V (1990). Introduction to Plant Disease Epidemiology. John Wiley and Sons, New York, USA.
COOPER, R M; FLOOD, J and REES, R (2011). Ganoderma boninense in oil palm plantations: Current thinking on epidemiology, resistance and pathology. The Planter, 87: 515-526.

GOGOI, R; SINGH, D V and SRIVASTAVA, K D (2001). Phenols as a biochemical basis of resistance in wheat against karnal bunt. Plant Pathology, 50: 470-476.

HARMAN, G E; HOWELL, C R; VITERBO, A; CHET, I and LORITO, M (2004). Trichoderma plant symbionts species - Opportunistic. Nature Resource, 2: 43-56.

HASAN, Y; FOSTER, H L and FLOOD, J (2005). Investigations on the causes of upper stem rot (USR) on standing mature oil palms. Mycopathologia, 159(1): 109-112.

HERMOSA, R; BELÉN, R M; CARDOZA, R E; NICOLÁS, C; MONTE, E and GUTIÉRREZ, S (2013). The contribution of Trichoderma to balancing the costs of plant growth and defense. International Microbiology, 12: 23-46.

KHAIRUDDIN, $\mathrm{H}$ and CHONG, T C (2008). An overview of the current status of Ganoderma basal stem rot and its management in a large plantation group in Malaysia. The Planter, 84: 469-482.

KOKKINAKIS, D M and BROOKS, J L (1979), Tomato peroxidase: Purification, characterization and catalytic properties. Plant Physiology, 63: 93-99.

LATHA, P; ANAND, T; RAGHUPATI, N; PRAKASAM, V and SAMIYAPPAN, R (2009). Antimicrobial activity of plant extracts and induction of systemic resistance in tomato plants by mixtures of PGPR strains and Zimmu leaf extract against Alternaria solani. Biological Control, 50: 85-93.

LIU, L; KLOEPPER, J W and TUZUN, S (1995). Induction of systemic resistance in cucumber against bacterial angular leaf spot by plant growth promoting rhizobacteria. J. Phytopathology, 85: 843847.

MAŁOLEPSZA, U and RÓZALSKA, S (2005). Nitric oxide and hydrogen peroxide in tomato resistance. Nitric oxide modulates hydrogen peroxide level in o-hydroxyethylorutin-induced resistance to Botrytis cinerea in tomato. Plant Physiological Biochemistry, 43: 623-635.

MARIMUTHU, S; RAMAMOORTHY, V; SAMIYAPPAN, $\mathrm{R}$ and SUBBIAN, P (2013). Intercropping system with combined application of Azospirillum and Pseudomonas fluorescens reduces 
root rot incidence caused by Rhizoctonia bataticola and increases seed cotton yield. J. Phytopathology, 161(6): 405-411.

MARTÍNEZ-MEDINA, A; DEL, M and ALGUACIL, $M$ (2014). Phytohormone profiles induced by Trichoderma isolates correspond with their biocontrol and plant growth-Promoting activity on melon plants. Molecular Plant Pathology, 40: 804-815.

MINCHIN, R; HILL, R; CONDRON, L; RIDGWAY, H; BALDAUF, S and JONES, E (2006). Effect of Trichoderma bio-inoculants on ectomycorrhizal colonisation of Pinus radiata seedlings. $8^{\text {th }}$ International Mycological Congress. Cairns, QLD, Australia, 21-25 August 2006. p. 204.

MOKHTAR, H and AID, D (2013). Contribution in isolation and identification of some pathogenic fungi from wheat seeds, and evaluation of antagonistic capability of Trichoderma harzianum against those isolated fungi in vitro. Agriculture and Biology J. North America, 4: 145-154.

MPOC (2017). http: / / www.mpoc.org.my / The_Oil_ Palm_Tree.aspx

NAHER, L; YUSUF, U M I K; ISMAIL, A and HOSSAIN, K (2014). Trichoderma spp.: A biocontrol agent for sustainable management for plant diseases. J. Economics and Sustainable Development, 46(4): 1489-1493.

NIKRAFTAR, F; TAHERI P; RASTEGAR M F and TARIGHI, S (2013). Tomato partial resistance to Rhizoctonia solani involves antioxidative defense mechanisms. Physiology Molecular Plant Pathology, 81: 74-83.

NUSAIBAH, S; LATIFFAH, Z and HASSAAN, A (2011). ITS-PCR-RFLP analysis of Ganoderma sp. Infecting industrial crops. Pertanika, 34(1): 83-91.

NUSAIBAH, S A; SITI NOR AKMAR, A; IDRIS, A S; SARIAH, $M$ and MOHAMAD PAUZI, Z; (2016). Involvement of metabolites in early defense mechanism of oil palm (Elaeis guineensis Jacq.) against Ganoderma disease. Plant Physiology and Biochemistry, 109: 156-165.

NUSAIBAH, S A; SAAD, G and HUN, T G (2017). Antagonistic efficacy of Trichoderma harzianum and Bacillus cereus against Ganoderma disease of oil palm via dip, place and drench artificial inoculation method. International J. Agriculture and Biology, 19: 299-306.

PRASANNA, R; BABU, S and RANA, A (2013). Evaluating the establishment and agronomic proficiency of cyanobacteria consortia as organic options in wheat-rice cropping sequence. Experimental Agricultural, 49: 416-434.

RAKIB, M R M; BONG, C F J; KHAIRULMAZMI, A and IDRIS, A S (2014). Genetic and morphological diversity of Ganoderma species isolated from infected oil palms (Elaeis guineensis). International J. Agriculture and Biology, 16: 691-699.

RAKIB, M R M; BONG, C F J; KHAIRULMAZMI, A and IDRIS, A S (2015). Aggressiveness of Ganoderma boninense and Ganoderma zonatum isolated from upper- and basal stem rot of oil palm (Elaeis guineensis) in Malaysia. J. Oil Palm Res.Vol. 27: 229-240.

RAO, G S; REDDY, N N R and SUREKHA, C (2015). Induction of plant systemic resistance in legumes Cajanus cajan, Vigna radiata, Vigna mungo against plant pathogens Fusarium oxysporum and Alternaria alternata - A Trichoderma viride mediated reprogramming of plant defense mechanism. International J. Recent Scientific Research, 6: 4270-4280.

RINU, K; SATI, P and PANDEY, A (2014). Trichoderma gamsii (NFCCI 2177): A newly isolated endophytic, psychrotolerant, plant growth promoting and antagonistic fungal strain. J. Basic Microbiology, 54(5): 408-417.

ROBINSON, L; JEGER, M J and XIANGMING, P (2009). Management of strawberry gray mould using mixtures of biocontrol agents with different mechanisms of action. Biocontrol Science Technology, 19: 1051-1065.

RUDRESH, D L; SHIVAPRAKASH, $\mathrm{M} \mathrm{K}$ and PRASAD, R D (2005). Effect of combined application of Rhizobium, phosphate solubilizing bacterium and Trichoderma spp. on growth, nutrient uptake and yield of chickpea (Cicer arietinum L.). Applied Soil Ecology, 28: 139-146.

SAMATHA, T; ACHARYA, R S; SRINIVAS, P and RAMASWAMY, N (2012). Quantification of total phenolic and total flavonoid contents in extracts of Oroxylum indicum L. Kurz. Asian J. Pharmaceutical Clinical Resource, 5(4): 177-179.

SARAVANAKUMAR, K; YU, C; DOU, K; WANG, M; LI, Y and CHEN, J (2016). Synergistic effect of Trichoderma-derived antifungal metabolites and cell wall degrading enzymes on enhanced biocontrol of Fusarium oxysporum f. sp. cucumerinum. Biocontrol, 94: 37-46.

SARIAH, M and ZAKARIA, H (2000). The use of soil amendments for the control of basal stem rot of 
oil palm seedlings. Ganoderma Diseases of Perennial Crops (Flood, J; Bridge, P D and Holderness, M eds.). Wallingford, UK: CABI Publishing. p. 89-99.

SARIAH, $\mathrm{M}$; $\mathrm{CHOO}, \mathrm{C} \mathrm{W}$; ZAKARIA, $\mathrm{H}$ and NORIHAN, M S (2005). Quantification and characterization of Trichoderma spp. from different ecosystem. Mycopathologia, 159: 113-117.

SHANMUGAIAH, $\mathrm{V}$; BALASUBRAMANIAN, $\mathrm{N}$; GOMATHINAYAGAM, S; MONOHARAN, P T and RAJENDRAN, A (2009). Effect of single application of Trichoderma viride and Pseudomonas fluorescens on growth promotion in cotton plants. African $J$. Agricultural Resource, 4(11): 1220-1225.

SHIVANNA, M B; MEERA, M S; KAGEYAMA, K and HYAKUMACHI, M (1996). Growth promotion ability of zoysia grass rhizosphere fungi in consecutive plantings of wheat and soybean. Mycoscience, 37: 163-168.

SHORESH, M; HARMAN, G E and MASTOURI, F (2010). Induced systemic resistance and plant responses to fungal biocontrol agents. Annual Review of Phytopathology, 48(1): 21-43.

SINGH, B N; SINGH, S P; SINGH, A and SINGH, H B (2011). Reprogramming of oxidant and antioxidant metabolites in root apoplast of sunflower by Trichoderma harzianum NBRI-1055 against Rhizoctonia solani. European. J. Plant Pathology, 131: 121-134.

SLINKARD, K and SINGLETON, V L (1977). Total phenol analysis: Automation and comparison with manual methods. American J. Enology and Viticulture, 28(1): $49-55$.

SUNDRAM, S; ABDULLAH, F; AHMAD, Z and YUSUF, U K (2008). Efficacy of single and mixed treatments of Trichoderma harzianum as biocontrol agents of Ganoderma basal stem rots in oil palm. J. Oil Palm Res.Vol. 20: 47-83.
SUSANTO, A (2009). Basal stem rot in IndonesiaBiology, economic importance, epidemiology, detection and control. Proc. of the MPOB-IOPRI International Workshop on Awareness, Detection and Control of Oil Palm Devastating Diseases. 6 November 2009, Kuala Lumpur Convention Centre, Kuala Lumpur Malaysia. p. 18-18.

TCHAMENI, S N; NGONKEU, M E L; BEGOUDE, B A D; NANA, L W; FOKOM, R and OWNS, A D (2011). Effect of Trichoderma asperellum and arbuscular mycorrhizal fungi on cacao growth and resistance against black pod disease. Crop Protection, 30(10): 1321-1327.

TORRES, G A; SARRIA, G A; VARON, F; Coffey, M D; ELLIOTT, M L and MARTINEZ, G (2010) First report of bud rot caused by Phytophthora palmivora on African oil palm in Colombia. Plant Disease, 94 (9): 1163.

TREUTTER, D (2006). Significance of flavonoids in plant resistance: A review. Environmental Chemistry Letters, 4(3): 147-157.

UTOMO, C and NIEPOLD, F (2000). The development of diagnostic tools for Ganoderma in oil palm. Ganoderma Diseases of Perennial Crops (Flood, J; Bridge, P D and Holderness, M eds.). CABI Publishing. p. 235-247.

VANITHA, S C; NIRANJANA, S R; MORTENSEN, C N and UMESH, S (2009). Bacterial wilt of tomato in Karnataka and its management by Pseudomonas fluorescence. Biocontrol, 54: 685-695.

YOBO, K S; LAING, M D and HUNTER, C H (2011). Effects of single and combined inoculations of selected Trichoderma and Bacillus isolates on growth of dry bean and biological control of Rhizoctonia solani damping off. African J. Biotechnology, 10 (44): 8746-8756. 